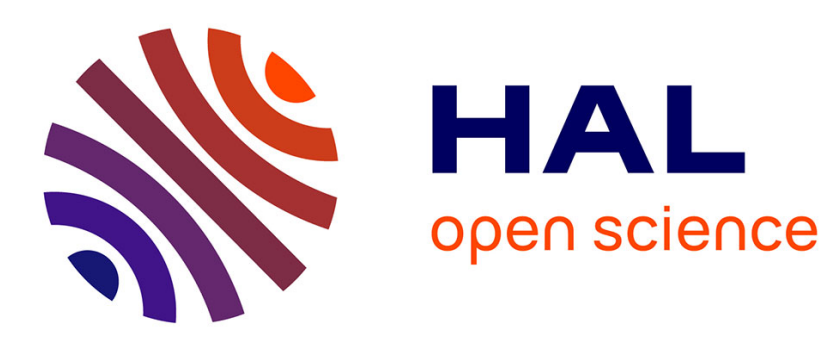

\title{
France: Centrality or Proximity, Consumption or Culture?
}

Anne Querrien, Laurent Devisme

\section{To cite this version:}

Anne Querrien, Laurent Devisme. France: Centrality or Proximity, Consumption or Culture?. Built Environment, 2006, Neighborhood centres in Europe: yesterday, today and tomorrow, 32 (1), pp.73-87. hal-02431230

\section{HAL Id: hal-02431230 https://hal.science/hal-02431230}

Submitted on 7 Jan 2020

HAL is a multi-disciplinary open access archive for the deposit and dissemination of scientific research documents, whether they are published or not. The documents may come from teaching and research institutions in France or abroad, or from public or private research centers.
L'archive ouverte pluridisciplinaire HAL, est destinée au dépôt et à la diffusion de documents scientifiques de niveau recherche, publiés ou non, émanant des établissements d'enseignement et de recherche français ou étrangers, des laboratoires publics ou privés.

\section{(이) $\$$}

Distributed under a Creative Commons Attribution - NonCommercial - NoDerivatives| 4.0 
France: Centrality or Proximity, Consumption or Culture?

Author(s): ANNE QUERRIEN and LAURENT DEVISME

Source: Built Environment (1978-), Vol. 32, No. 1, Neighbourhood Centres in Europe:

Yesterday, Today and Tomorrow (2006), pp. 73-87

Published by: Alexandrine Press

Stable URL: https://www.jstor.org/stable/23289487

Accessed: 03-01-2020 13:14 UTC

JSTOR is a not-for-profit service that helps scholars, researchers, and students discover, use, and build upon a wide range of content in a trusted digital archive. We use information technology and tools to increase productivity and facilitate new forms of scholarship. For more information about JSTOR, please contact support@jstor.org.

Your use of the JSTOR archive indicates your acceptance of the Terms \& Conditions of Use, available at https://about.jstor.org/terms

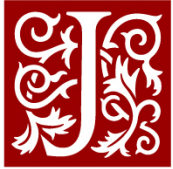

Alexandrine Press is collaborating with JSTOR to digitize, preserve and extend access to Built Environment (1978-) 


\title{
France: Centrality or Proximity, Consumption or Culture?
}

\author{
ANNE QUERRIEN and LAURENT DEVISME
}

\begin{abstract}
The idea of the neighbourhood as a planning unit has not been prominent in France. Post-war reconstruction of housing took place around the existing town centres, in the large cities often as huge housing complexes - grands ensembles. In time these housing estates were provided with health and sports facilities, child care and residents' meeting rooms - an embryo of neighbourhood community places. Today, the tension between centrality and mobility and proximity and identity is plain for all to see. On one hand there are the mega-structure shopping centres, serving as nodes for the whole metropolitan area, on the other hand there is a call for smaller local centres to provide convenience stores as well as sociable spaces. These centres are especially needed in the poor neighbourhoods, but there they are also threatened by the privatization of services. Some observers note that the bad conditions and the sterile environments of the grands ensembles was one of the causes of the unrest in French housing estates in 2005.
\end{abstract}

Several current theories indicate the importance of mobility in everyday life, the development of the 'city as you wish' and, as a consequence, the decline of neighbourhood structures. In his book Métapolis, F. Ascher wrote: 'real neighbours of the metapolis are neighbours who ignore their proximity' (1995, p. 150). In this perspective, neighbourhood centres are considered rather as 'has beens', a characteristic of urban planning movements of earlier times. Indeed, centres in new cities or new settlements were important after the Second World War, but today they are an outdated notion.

Two different qualities are linked to centrality. In economic terms, the emphasis is on accessibility for goods and persons: the centre polarizes space on a large scale, with dense activities. In political terms, centrality is linked symbolically to identity. Traditionally, the centre is where you find the church and the town hall; it is frequently made up of monumental buildings and public space.
These qualities are quite the opposite of those of a neighbourhood and, through case studies, we will show how they were linked in recent urban history.

Following an overview of the relation between centrality and neighbourhood, we discuss several developments in the 1960s and 1970s. The focus of one case is more on the socio-political level, the others are on the urban level. Urban conceptions have changed markedly between the time when they were launched and the present; in the third part we examine some expectations of the local centres today.

\section{Political and Urban Conceptions}

During different periods in urban history, the ideas linked to the need to build a new centre have had several meanings. According to the type of political regime, the problems identified by the state, and the architectural and technical principles of the time, new 
centres developed different qualities. We can point to at least three conceptions of new centres:

- Strategic goals to reinforce statecentered conceptions of the nation led to the construction of new political centres : new towns in the eighteenth century in France created by Vauban and in the nineteenth century by Napoleon III (La Roche-surYon, the new capital of the provincial territory of la Vendée, for example). The idea was to create a new regional capital, to counterbalance other types of power and mainly by means of military forces. In the nineteenth and twentieth centuries, the process of colonization led to the building of many new towns in North Africa, so as to enable incomers to live in a modern way different from the local ones. The aim was also to 'show the way' with a strong vision of building activities: various conferences up until the 1930s show the importance of what is called the French school of urbanism. But contrary to other countries like Brazil (Brasilia) or India (Chandigarh, capital of Punjab and Hariana), France was not concerned with the creation of a new capital in the last century.

- Regulation of centripetal forces was sometimes transferred to polycentric plans for metropolitan areas: London in the 1940s, Paris in the 1960s. These plans included new towns which were located a considerable distance from the original centre. According to the ideologies and to the demographic and economic contexts, these new towns all developed new centres, sometimes inspired by garden -cities, sometimes not. In the 1960s with strong demographic pressure and after the building of massive housing estates - the so-called grands ensembles" and 'ZUP' (zones à urbaniser en priorité) - both technicians and politicians tried to transform the suburbs into 'real cities'. Delouvrier, one of the most important planners of the French new towns, said:
In spite of making housing plots, we think that we have to bring services, universities, prefectures, sporting areas, in the heart of the new suburbs which will not be suburbs any more and will be named new towns. But these new towns are the modern way in which Paris continues to grow and not fully autonomous towns we could have located anywhere. That's what we want to do. (Delouvrier, 1961 in Ricard, quoted by De SaintPierre, 1998, p. 10)

We can point out that urban planners, until the 1980s had always had to deal with the regulation of centripetal forces. It is rather the opposite nowadays with many thoughts on how differing centrifugal forces can restrict sprawl.

- Over a period of more than 50 years there have been several approaches to the problem of how to build a new life in the new towns. Are there recipes? What is the soul of a town? What kind of services are needed in new collective housing estates and for whom? In contrast to Central Business Districts and so as to avoid monotonous outskirts, several planners thought about new conceptions of centrality for the people who lived there. The criticism of functionalist views often led to culturalist ones or to the rediscovery of the nature of cities made up of density and diversity. It can also be related to the criticism of everyday life in the modern world (Lefebvre, 1968, 1970;, Mayol, 1994).

This third meaning will now be developed and we will discuss the difficulties encountered by those who had and have to think about and build the relations between centrality and proximity. That is what is at stake in neighbourhood centres, because of the nature of such public spaces. What does it mean to live in new towns? What does it require?

The idea that a centre is necessary for a neighbourhood is fairly recent in France. In the traditional French village or small town the centre comprises the town hall and the church near a large square, and these three main elements stand beside the main road which links the village to the ones nearby. 
Several types of centralities are gathered in what appears not as the 'neighbourhood centre' but as the local centre, the place attracting all people around to its various activities. When former rural localities became urban ones, the old centre remained for a while, until the new working-class inhabitants elected representatives able to negotiate with the State for the development of new urban facilities.

In old large towns the town hall was a huge monument ruled by the local bourgeoisie, with a lot of social and educational services for workers. The beginning of the idea of 'neighbourhood centres' was to get those services closer to the people, generally on the ground floor of residential buildings. The local Catholic Church settled in the new working-class quarters. The socialist movement is the only political movement which tried to build new urban settlements organized around a neighbourhood centre. Several garden cities were built around Paris. These garden cities were inhabited by civil servants, and middle-class people, rather than by working-class people. Today the economic equilibrium of those neighbourhoods is quite difficult to maintain especially in the shops around the squares.

After the Second World War the main concern was the reconstruction of buildings destroyed by the war, and the creation of new housing for workers in the construction industry as well as in the automobile and appliance factories in the surroundings of the big towns. The existing centres seemed quite able to welcome the new inhabitants. Around Paris, Lyon, Marseille, Lille, Rennes, Nantes and all big French towns grands ensembles, huge social housing estates, were built from the beginning of the 1950s to the mid-1970s. So the main problem was to organize transport for the people to their jobs, and to the centre of the agglomeration, but not so much to the local centre nearby. It was generally much easier to go from the social housing estate to the big factory or to the mine than to the town centre.
The centres had developed at road crossings, bringing into the centre not only the people living there, but everybody going through the centre on their way elsewhere. As traffic grew, new roads were built around the localities to divert through traffic. The new mapping of car traffic supported the big urban centres, and passed by the centres of the suburban towns. There, the shops, hotels, restaurants were less visited and began to decline. The new roads around the main towns were the sites of the development of new commercial centres, for both inhabitants and travellers.

Local municipalities quite soon found that the social and mental health problems appearing in the new 'rational' settlements needed measures similar to those already taken by the municipalities in the old industrial towns: sports facilities and organizations and child care facilities, such as kindergartens and afternoon activity centres for school children. This was the beginning of the neighbourhood centre.

So the residents had a place to gather, to organize, and to help each other, in association with the local municipality and within the framework of dwellers' unions. It appeared that, little by little, as more and more of the inhabitants of those estates were immigrants and had lost links with the local municipality and local associations, these Locaux collectifs résidentiels, situated on the lower levels of the buildings with the key kept by the dweller union, were not open to everybody, and could not be seen as neighbourhood centres.

A new movement called Groupes d'action municipale appeared in several towns, especially Grenoble, and asked for technical neighbourhood services to be created, and for neighbourhood technicians or social workers to be given the means to make the little improvements in the neighbourhood asked for by inhabitants.

The 'neighbourhood centre' was not a concept for architectural studies in France: the size of the projects studied in the 
architectural schools at that time was much bigger, and the idea that architects also could design small projects had not arrived. Architecture students were taught to design towns for all and houses for rich people, not neighbourhoods.

\section{New Urban Centres put to the Test}

The New Urban Centres of the 1970s, the French New Towns, especially Evry

After the end of the Algerian war, and the influx to France of many new citizens, who were not the ordinary immigrant workers as in Algeria they had belonged to the ruling and middle classes, the creation of new neighbourhoods took on a new dimension. It was not possible to carry on building housing estates for workers; it was necessary to offer these new citizens actual urban estates, with all the aspects of life which existed in towns. The first cities built in this new context,
Sarcelles and Créteil, appeared not complex enough to support a full urban life, which cannot be reduced to housing, shopping and compulsory education. The new planning scheme drafted by De Gaulle's administration for the Paris region, the SDAURP, (Schéma Directeur d'Aménagement et d'Urbanisme de la Région Parisienne) in 1965, created five new towns around Paris, to organize the urban growth around new urban centres, new towns with all the dimensions of a town. The first dimension given to those new towns was the administrative one: five new départements (the French main administrative territorial division) were created in the Paris region, and huge administrative buildings were erected in quasi deserts in the future centres of those départements: Evry, Cergy, Créteil.

The case of Evry is quite emblematic of the French way of thinking at that time. Evry is south-east of Paris, near the river Essonne, and not far from the river Seine. It is a pleasant landscape of water, small

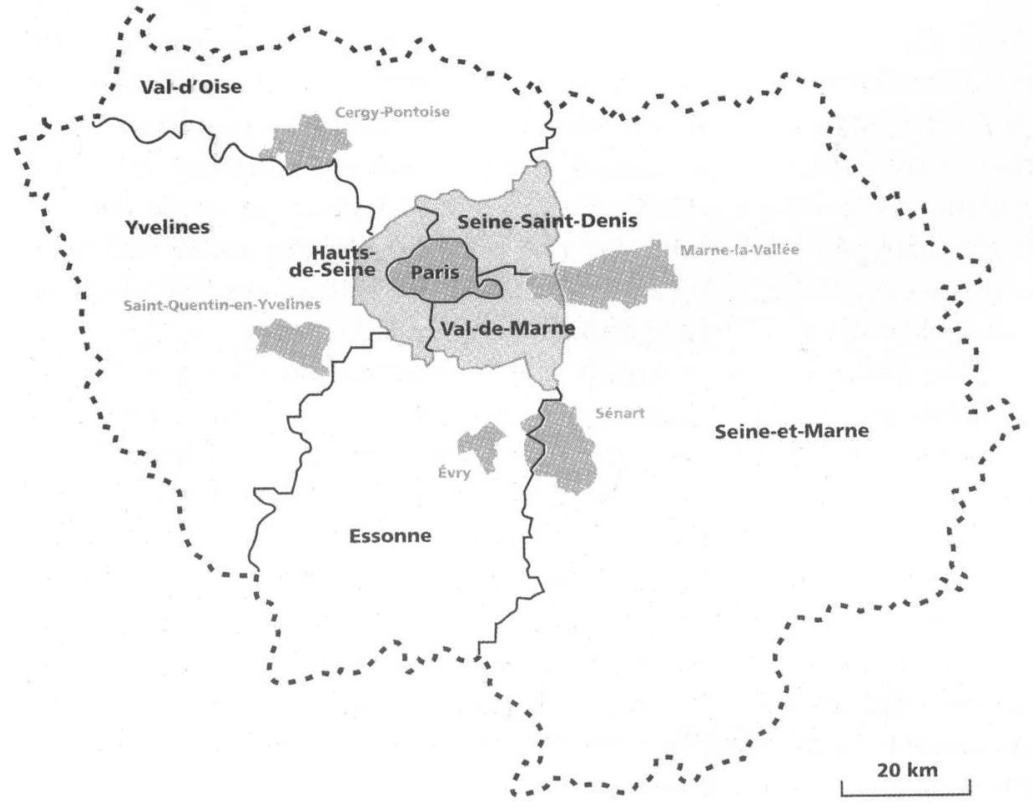

76
Figure 1. The location of the Parisian new towns. 
hills, and plateaus. This part of the Paris region began to develop spontaneously, with people building typical suburban houses between the two world wars. There was some industrial development in the town of Corbeil-Essonnes, a little further south-east. But the real industrial development began in the 1950s with the opening of the Orly airport, and the settling of logistics activities in the area. A highway was built from Paris to the airport, and further to the south of France. The plateaus appeared ready to be urbanized, with the infrastructure already there.

As Evry was a good place for agriculture, the landowners were big farmers with large land holdings and were the dominant figures in the local council at the beginning of the 1960s.

Seen from a plane or on a map the plateaus appeared the very place to build a new town; the only person to convince was the landowner, the mayor of the commune. The location of Evry was not far from CorbeilEssonnes, but certainly not in the old centre, where the Communist Party ruled. The first buildings to be constructed in the new town were the town hall and the social housing estates for the workers who built the town hall.

A public body, the Etablissement public d'aménagement de la ville nouvelle d'Evry (EPEVRY), was set up to plan and manage the building of the new town, which covered the area of four communes with the new town centre in the middle. Their links were conceived through what is called, in France, intercommunalité. The old municipalities were left small territories to rule separately, but

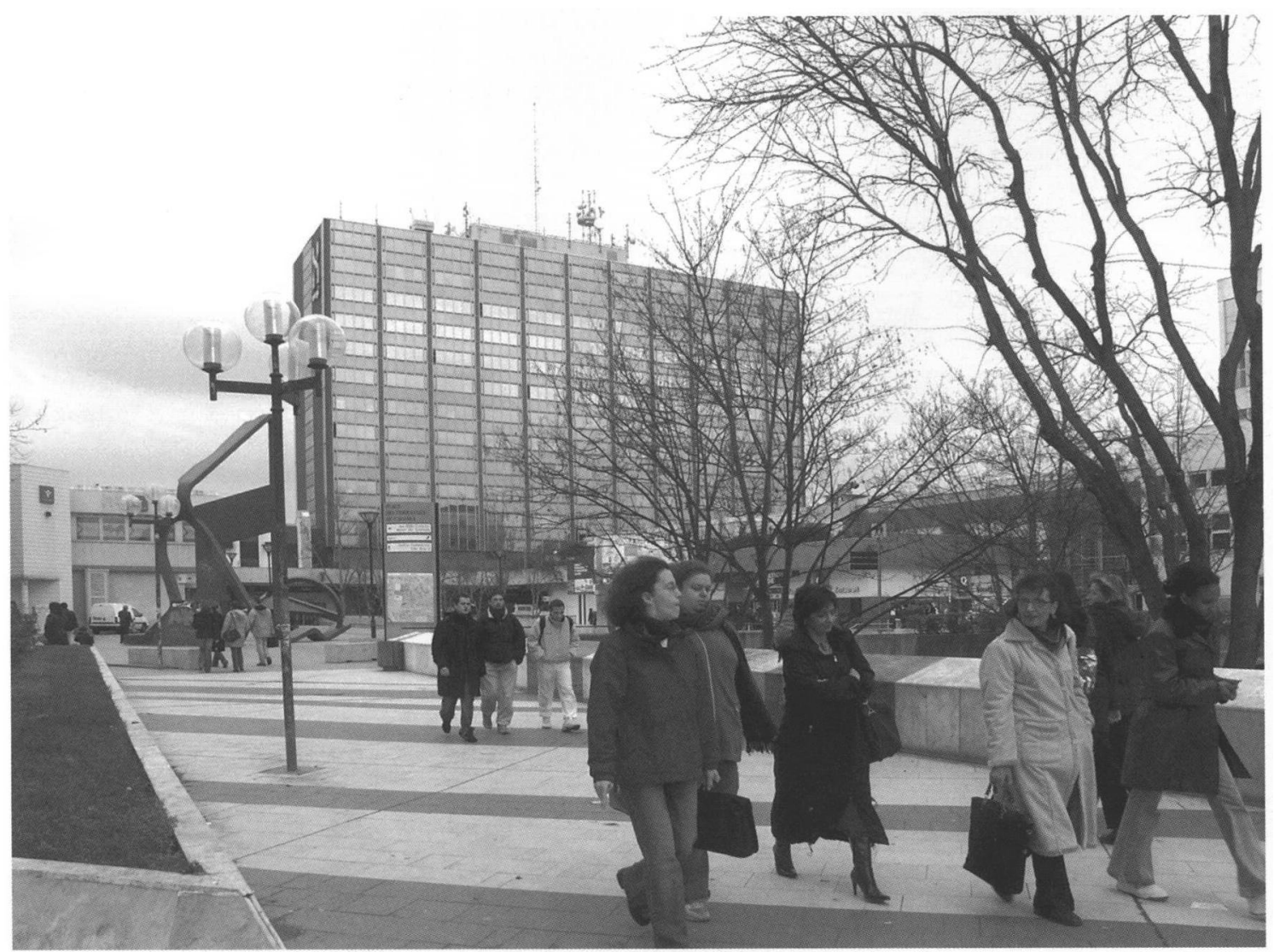

Figure 2. Separated pedestrian walk way. (Photo: Marie Claire Bordaz) 

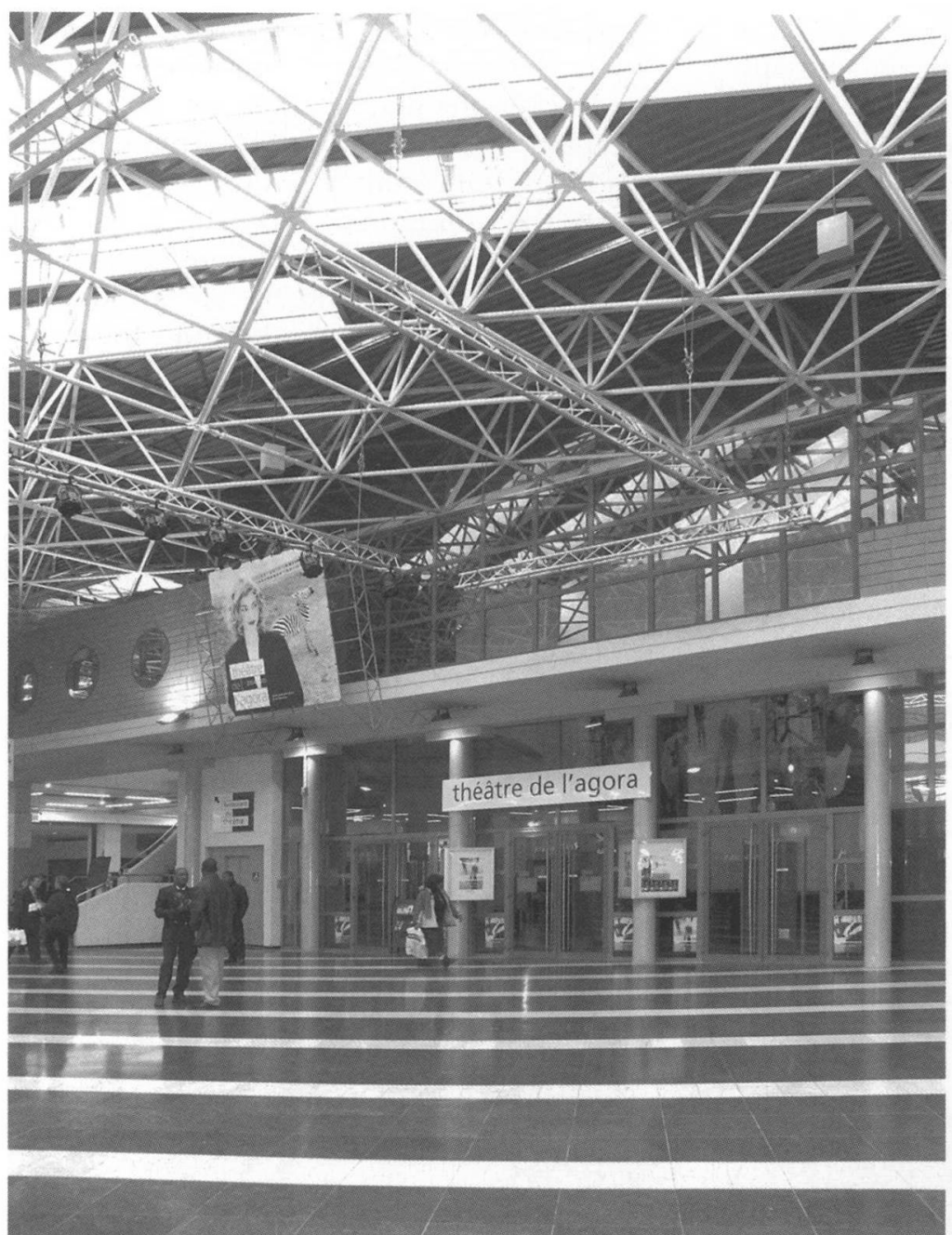

Figure 3. Theatre linked with the commercial centre. (Architects: Fabre et Perrottet; Photo: Marie Claire Bordaz) they strove to take back control of the whole urban development as little by little the EPEVRY disappeared. They joined together in a Syndicat d'agglomération nouvelle (SAN), gathering the municipalities affected by the new town. Recently the commune of Ris Orangis, close by, which was not invited at the beginning to join the new town because its mayor was a member of the Communist Party, has entered the SAN to manage its urban planning, housing programme, and several cultural and economic facilities in the new town framework. Like other French new towns Evry is organized in sectors surrounded by rapid freeways, which are not easy to cross; in the case of Evry it was decided to separate cars and pedestrians.

Evry's Agora is a typical example of the 1960s, attracting large numbers of visitors, among them people from the eight Evry neighbourhoods, including those from the housing projects which are home to around 10,000 people. The Agora has a huge commercial centre of regional dimension, under the Carrefour brand, access to which is possible from the highway, and from roads coming from all round to a big car park underneath. The whole establishment is massive, but none of it can be seen clearly from the outside; you must know that it 
Figure 4. Evry's Agora: commercial centre. (Photo: Marie Claire Bordaz)

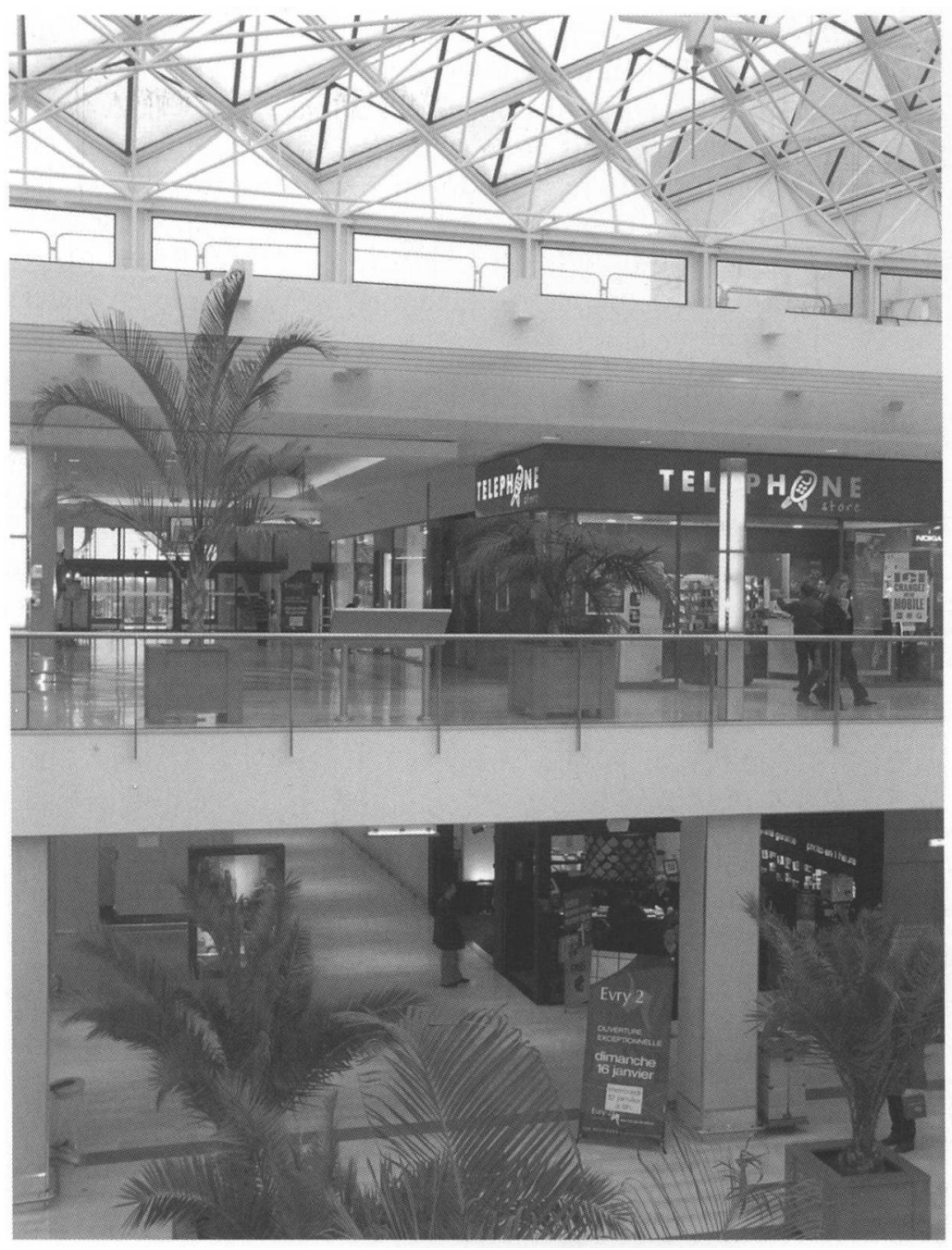

and new ways of programming facilities. For instance, in the different neighbourhoods centres were organized in the basement of the building, or at the first pedestrian level, to welcome youngsters and mothers. But when the inhabitants grew older, the layout was not as efficient as it was for them when they were young. Moreover, nothing was proposed for young adults often out of work because of the economic conditions. French housing policy changed in 1977 with the Housing Reform Act. The inhabitants of the centre of Evry, of the neighbourhoods around the Agora, by now are fairly poor; their income is around half the average in the region. It is 
quite difficult to balance the budgets for the social and cultural facilities, and even for the commercial centre, without pouring in a lot of public money. The new French policy of urban renewal intends to pull down some buildings where the people are too poor to participate in local life.

Nobody knows if the centre designed in the 1970s for people employed mostly in the public sector will meet the needs of a new population with a higher degree of culture and the means to move easily, especially to go to Paris, or all over the Paris region for cultural activity. A university was created in the 1990s to support the Evry centre. Some new enterprises have settled close to the university. But the concept of a departmental centre in which everything converges as in the old town centre, seems no longer viable. Evry is becoming a neighbourhood centre in the Paris polycentric region: it gathers together all people who share the same local facilities, it is a regional sub-centre.
Secondary Centres in 'the Rest of France': Villeneuve (Grenoble), Le Mirail (Toulouse) and Colomiers

In the 1960s and 1970s, several urban experiences showed the importance of sociocultural functions in new centres. In some regions, politicians and urban planners tried to achieve the opposite of the modern style realizations frequently seen as monotonous, composed only of housing. This is the case for the new town of Le Vaudreuil, approximately $20 \mathrm{~km}$ from Rouen with specific patterns of the germe de ville (the town's centre). It is also the case for Grenoble with the new town of Villeneuve. A real new centre had to deal with questions such as how to link different housing areas and achieve a desirable density. Centrality was seen as a public service to the local community. Some of the planners visited social-democrat developments in the Northern Europe such as Tapiola in Finland, the satellite-towns of Stockholm,

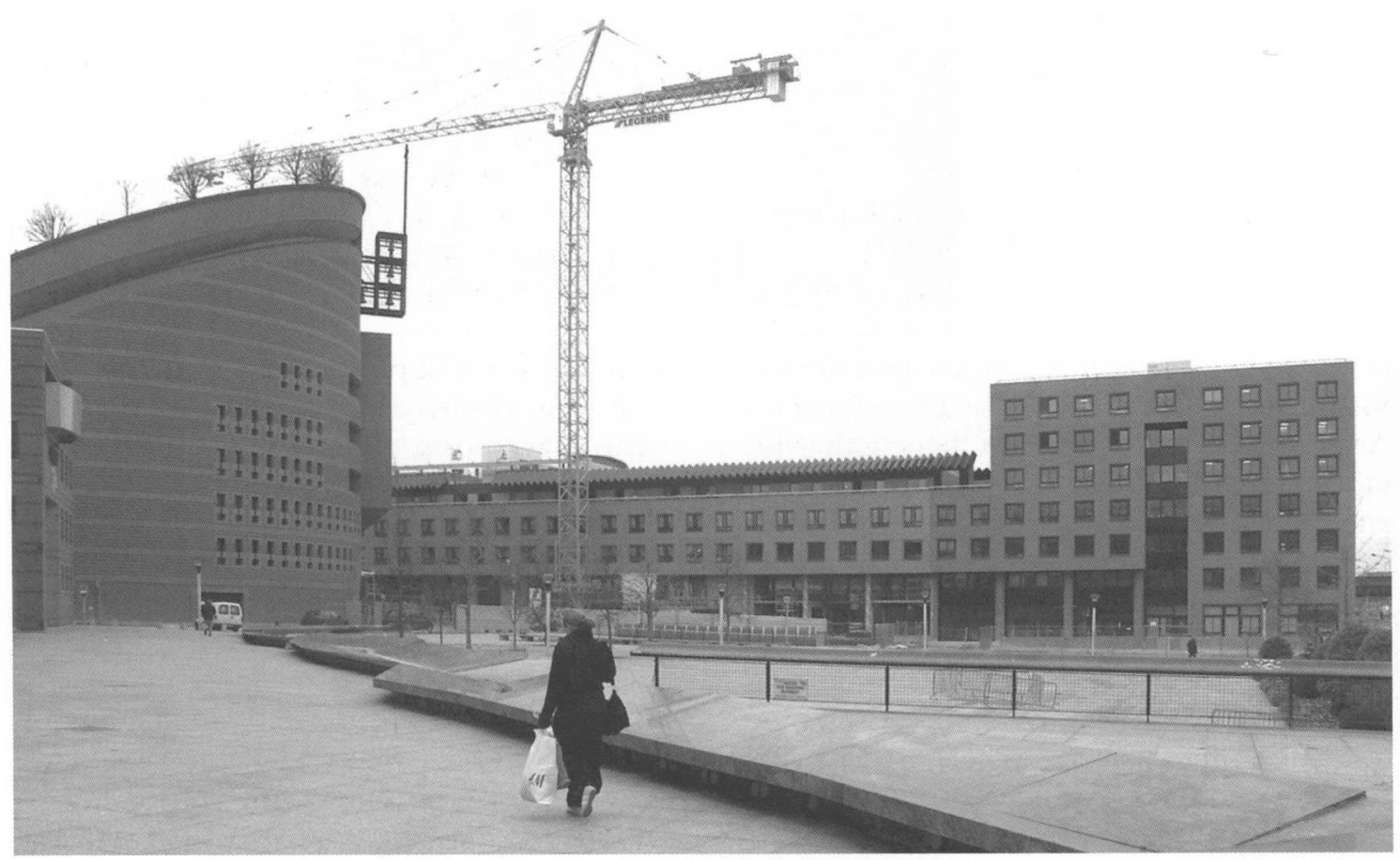

Figure 5. The building of new students' housing near the Evry cathedral. (Architect: Mario Botta; Photo: Marie Claire Bordaz) 


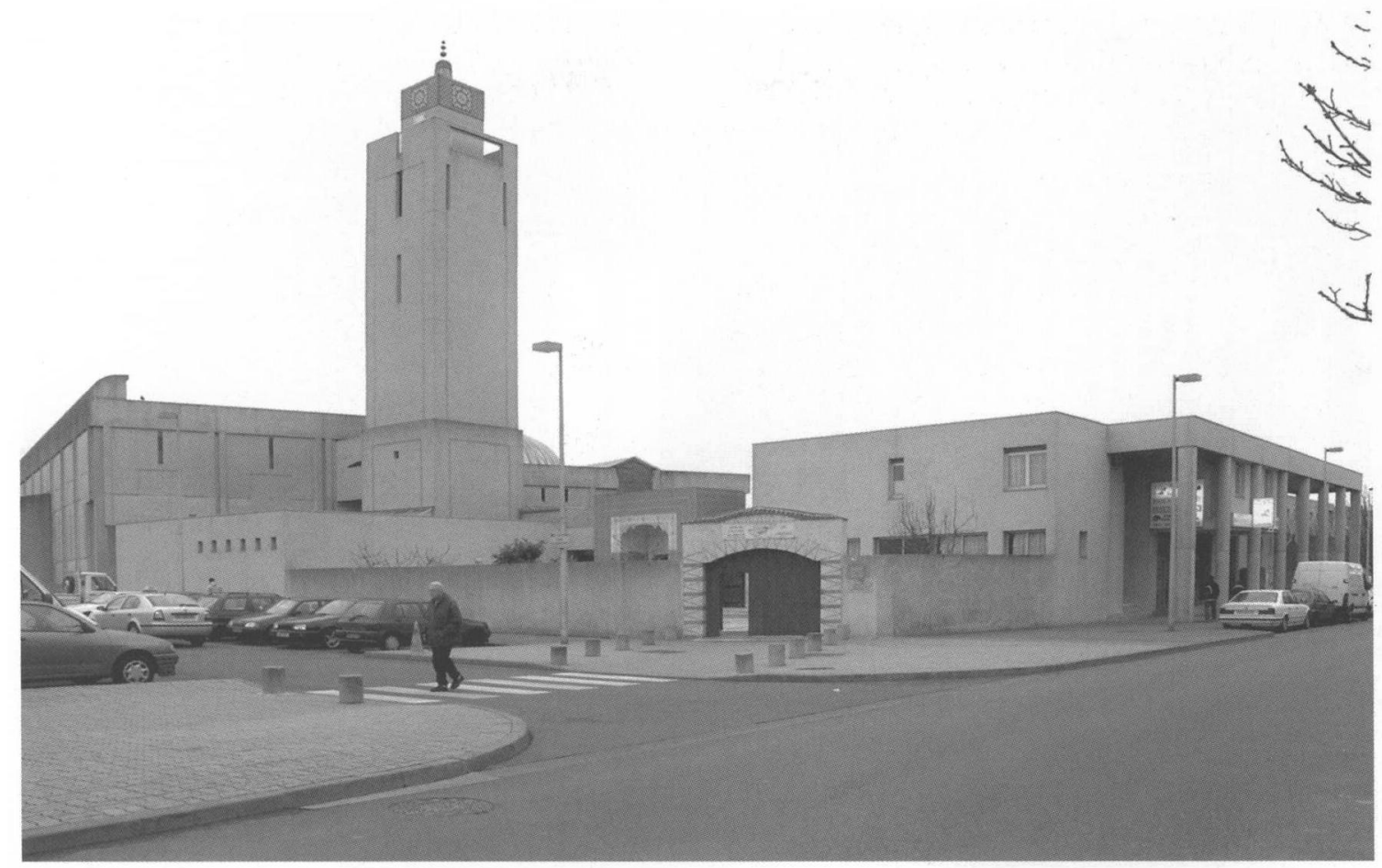

Figure 6. Evry's mosque. (Photo: Marie Claire Bordaz)

and the new town of Cumbernauld in Scotland. Structurally speaking, the centre was placed above a car park area and linked to the different quarters through footbridges. 'Megastructural proposals' were supposed to achieve the integration of new groups, in the same way as schools and social interactions could. How could both architecture and urbanism (we spoke of 'urbatecture' in Grenoble) facilitate social life? This urbatecture was a structure opposed to master plans. Its organizational principles were urban density, street-corridors, continuity of the constructed buildings with the existing city, urban parks. In Grenoble, it was an attempt at reconciliation between architecture, town planning and civil engineering. But it was also linked to municipal socialism, with the priority given to social housing, urban facilities, and an interest for what happens after working hours. The emphasis was also put on the virtues of art in public spaces. All spatial arrangements were supposed to accelerate the integration of new populations: lifts, entrances with mail boxes, benches, street lighting and shop windows. The results were often contrary to these goals because the social mix of homeownership and social housing was not sustainable: homeowners did not want their children to go to school with children of social housing renters. So they left their flats and sold them to new people, whose social profile was nearer that of social housing renters. The neighbourhood became de facto a social ghetto.

We can consider two projects realized in the same decade (the 1960s) within the metropole of Toulouse in south-west France. On one hand, through massive state credits, a "'new town"' was built, called Toulouse-le Mirail, supposed to reach 100,000 inhabitants. The goals have not been achieved and the area now concentrates a poor population and represents a social problem in the metropolitan area.On the other hand, less than $5 \mathrm{~km}$ away, outside the ring road, 


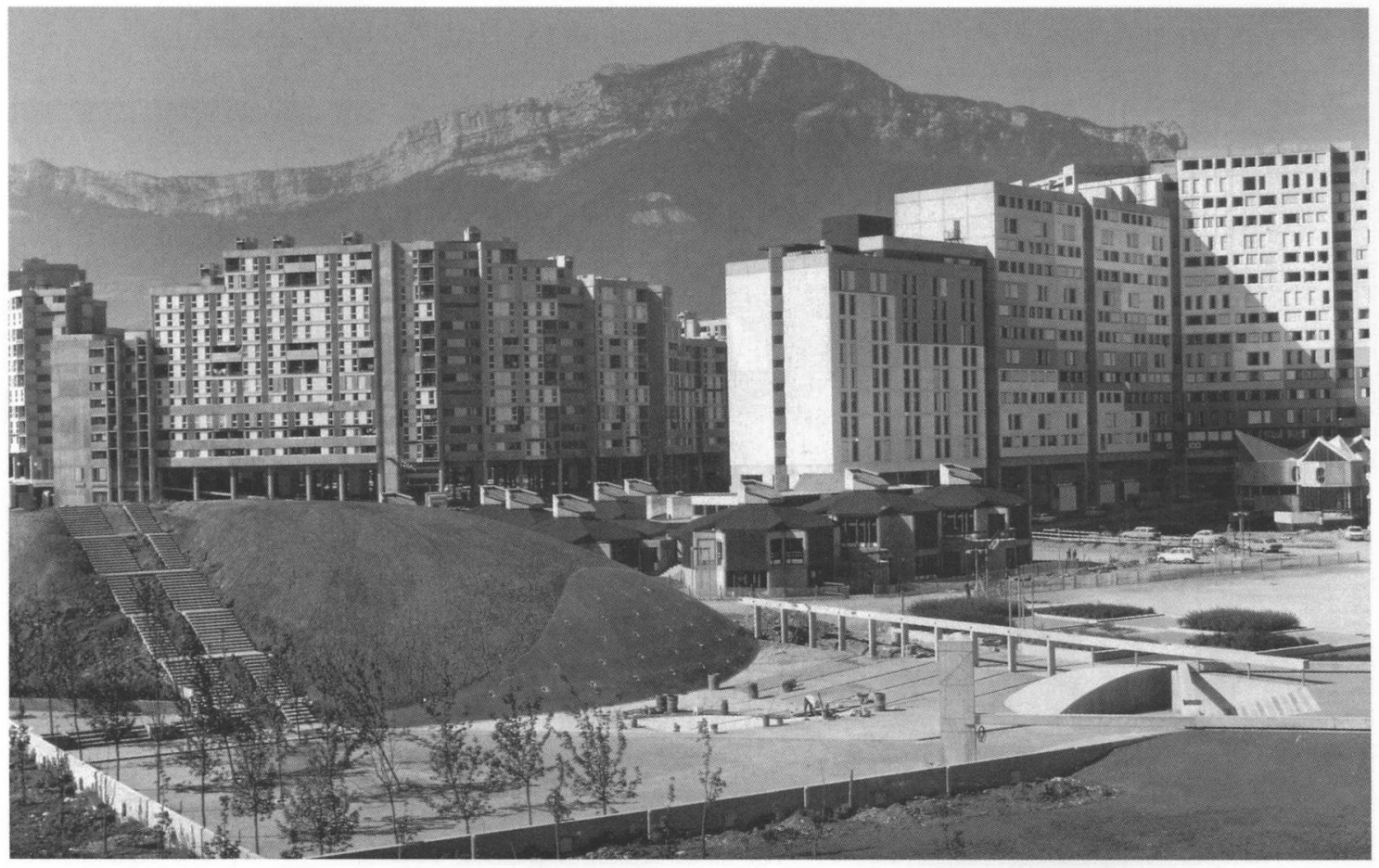

Figure 7. The Arlequin district, Grenoble, 1973. Green spaces, schools and housing. (Source: Photographer of S.A.D.I)

Colomiers did not want to be a suburbanized space like the others and its politicians also decided to create of a 'real City' - named 'Colomiers-Ville Neuve'. There a centre has recently been built so as to provide the city with the facilities frequented by middle-class populations.

Both the planning and architecture of Le Mirail (plans realized by Candilis, Josic and Woods in 1960) aimed at avoiding the usual framework of the master plan. Four ideas dominated: adaptation to the site, predominance of the pedestrian, avoidance of monotony and platitude, definition of the identity of the new town. It was also based on a linear concentration of urban activities, giving the 'street' a new prestige and linking five districts of 20,000 inhabitants.

This structure unifies all the new town districts to 'give everyone the enjoyment of all the collective functions'. Parallel to the street centre runs a green zone made up of gardens and parks. "The "centre street" is the domain of the pedestrian freed from the bondage of the automobile; it adapts better to the spirit of the changing mobility and expansion of our times' (Candilis, 1975,

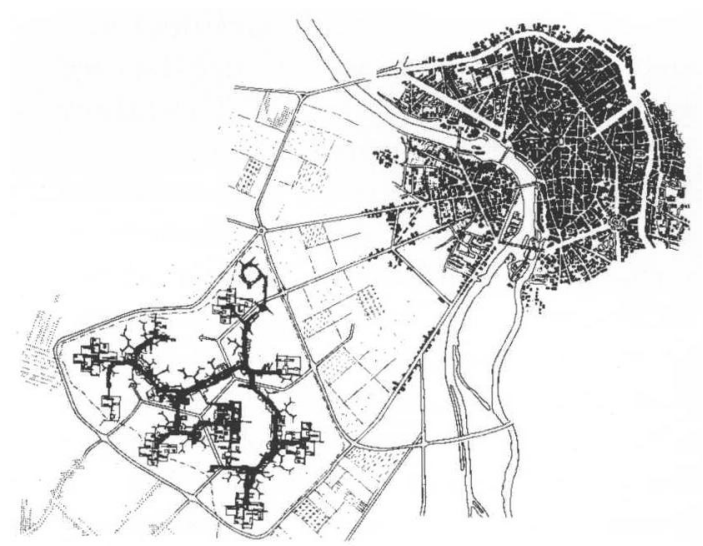

Figure 8 . The city of Toulouse and the new urban structure of Le Mirail. (Source: Candilis, 1975, p. 13) 
Figure 9. Le Mirail. View of the building of the new linear centre.
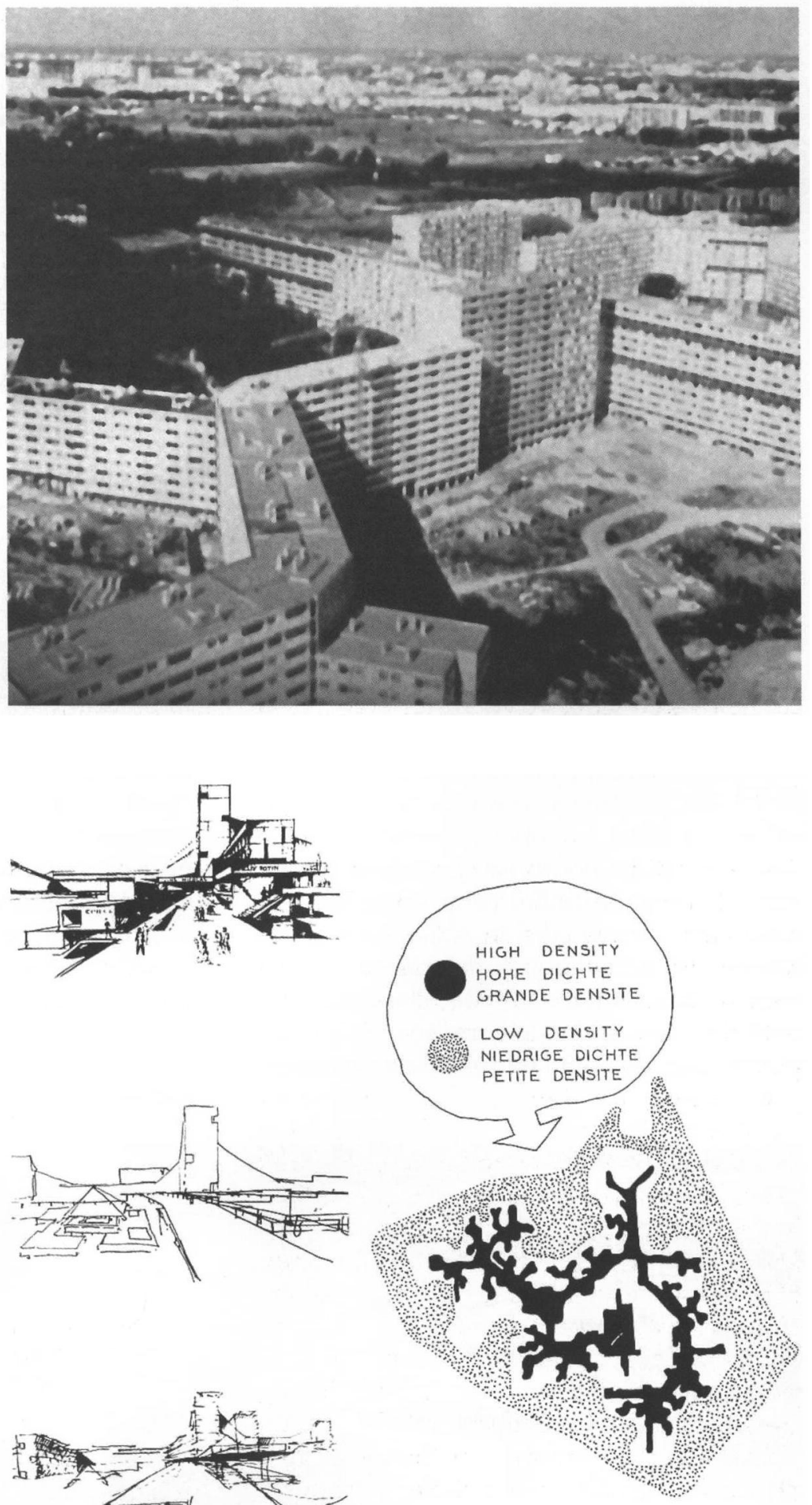

Figure 10. The distribution of density in Le Mirail.

(Source: Candilis, 1975, p. 19)

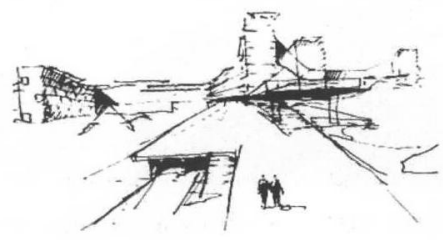


p. 19). This linear centre had to include multiple points of contact between means of transportation, dwellings and activity areas which were grouped around squares and free passages. For children's safety, the whole street was located $4 \mathrm{~m}$ above ground level with automobile circulation at the lower level. The linear street was supposed to belong to everybody and enable both spontaneous demonstrations and daily activities... It aimed at being the backbone of urban life in the new city, even if an important area was reserved for a commercial centre. The major goal of the linear centre was to arouse the interest in taking walks, stressing the possibilities of discovery. 'People can gather and discuss matters, claiming their legitimate rights' (Candilis, 1975, p. 83). High-rise buildings were grouped along this linear centre (with five, nine and thirteen floors).

A whole unit called la maison de quartier concentrated collective functions. As a consequence, the pedestrian street became a meeting place for the community. A multifunctional theatre-room was completed with exhibition halls; schools and nursery schools were meant to be an integral part of the surrounding apartment complexes. Parents were supposed to take an active part in the schools. In the Bellefontaine quarter (one of the five districts), the schools, standing on a central square, are widely transparent so that parents can see their children at any moment of the day!
The architects wanted to build a total environment, more open and diversified, for daily life where everyone is able to choose and adapt his or her particular lifestyle within the community. At the same time they defended the idea that the whole is intentionally imprecise and informal, thereby in opposition to formal buildings. We can see in this project both the modern heritage and its criticism. The book written by the builders during the construction of the town puts the emphasis on the primary importance of the town-planning concept and points out several dificulties: 'in spite of the important help offered by Monsieur Louis Bazerque, then mayor of Toulouse, we neither had a rational programme nor the necessary financial means to carry out this enormous job' (Candilis, 1975, p. 110).

In fact, in the last three decades, this project has deteriorated. Made up of social housing, in a context of economic and social crisis, this new city concentrated, step by step, poor populations, unemployed workers who could not go elsewhere while more affluent groups became owners of single-family houses. Several facilities were little used and different districts were stigmatized. As a consequence, le Mirail became a priority quarter for the so-called "politique de la ville", urban policy concerning the evolution of the social housing estates built in the 1960s and 1970 s. One of the recent actions consisted of pulling down the concrete overhead walkway
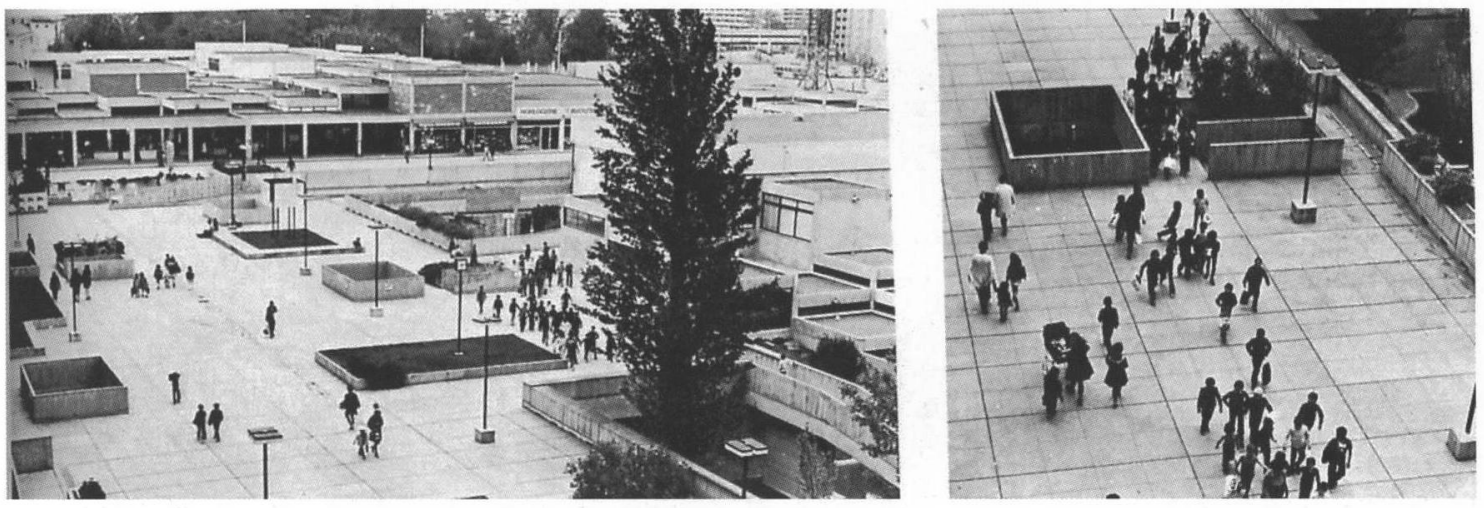

Figure 11. Urban life on the linear centre of le Mirail. (Source: Candilis, 1975, p. 39) 
under which incidents like fires took place. Major investments were made after the 2001 explosion at the nearby AZF chemical factory.

In Colomiers (as in Herouville-SaintClair, a new town near the city of Caen in Normandy), each of the five new new districts (planned in 1960) had varied facilities and a micro-centre. The central district remained an uncertain space until the creation of a new town hall with a great square in the 1990s. Apart from the surroundings of this building, various constructions are reminiscent of the outskirts of Toulouse: industrial zones, the old village along the ancient road linking Toulouse to Auch. More recent projects have attempted to complete, reinforce, and dynamize the centre. As one of the politicians of the town said, it was necessary to focus on the creation of a soul for the city rather than on promoting projects to make the centre. There were 3,100 inhabitants in the city of Colomiers in 1954, more than 50 years later there are ten times that number. Within this time, we can point out three periods:

- In the 1960s, with the development of aircraft industries (Airbus) and a strong desire of the mayor not to allow the spread of an anarchic urbanization, it was decided that the city had to be planned and not market-driven. A master plan was drawn up; the architect wanted a "'town of a human scale', just the opposite of le Mirail even if the comments were sometimes the same: for instance a pre-organized collective life was built, hence the realization of facilities such as a central post office, a police centre and commercial units erected in the 1970s.

- In the 1970s and 1980s, the different districts were built, free bus lines were put into practice. For the central district (last to be built, in contrast to le Mirail), silo car-parks were installed, a new commercial centre was set up, the weekly outside market moved from the old village, and a municipal cinema was built. As regards urban conceptions, it had to be different from modern ones, of car dependence. Several surveys were made, sometimes inspired by Patrick Geddes's methods.

- In the 1990s, a new town hall was opened and controversies arose over the central area status: on one hand, there was the wish for greater density and more commercial spaces in the central district even if it seemed to be difficult to attract retail from the metropolitan ring road or the huge spaces with easy car access; on the other hand, inhabitants preferred to have more green spaces.

Today, more reference is made to the street and to public spaces, but some planners favour friendly spaces rather than crowded and dense regroupings. At the beginning of 2000, one of the plans for the centre highlighted the desire for 'traditional
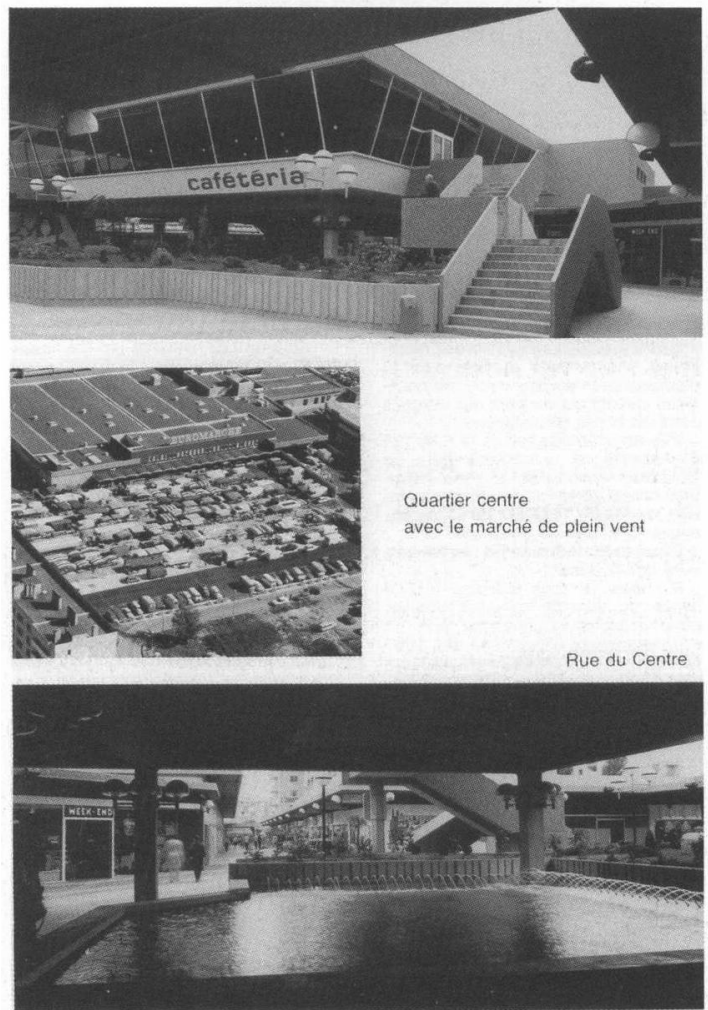

Figure 12. Images of the centre of Colomiers at the beginning of the 1980s. 
urban organization'! Several actors refer to the image of 'urban villages', which would be more likely to favour social links, to develop the feeling of belonging to the city. Inside Toulouse metropolis, there are various developments on the model of gated communities which sometimes appear as a solution to urban growth and to the fear of the anonymity of sprawl; not far from new urbanism doctrines. The problem in Colomiers is to know whether the goal is to achieve a town centre, a central district for the western part of the Toulouse region, or to realize another district among others with facilities in close proximity. Prospects are not the same and the means to achieve urban images are far less important than in the 1970s. Today, a new library and a new adminstrative building are planned in the centre of the city. The accessibility of the centre is still not obvious and major investments concern the redefinition of roads transformed into boulevards with cycle paths. A public station for a new Metro line could be very attractive but it depends on public investments in the metropolitan area. If it becomes easier to go to the central station of Toulouse, will Toulouse inhabitants come to this centre? Certainly not. While both a neighbourhood centre and the town centre, it is not yet a metropolitan one.

\section{Promises and Disapointments of Neighbourhood Centres. What are the Main Questions Today?}

As already mentioned, neighbourhood centres in France are facing a new situation in which they are no longer thought of as autonomous centres, gathering an urban settlement around them, but as nodes in metropolitan networks, in which mobility is the first rule. The demand for centrality is not decreasing but there is a desire for identity, for a difference between one neighbourhood centre and another, and a demand for all kinds of services. At the same time, there are attempts to develop metropolitan centres often linked to major shopping centres. Two scales are thus clearly distinguished, some planners speak of local public spaces on one hand and of metropolitan public spaces on the other. The major trends are the development of outof-town shopping centres, and the increase in developments without strollers inside. So local structures have to be reinvented. For example, a national public administration for the planning and restructuring of commercial and craftsman's spaces, Etablissement Public National d'Aménagement et de Restructuration des Espaces Commerciaux et Artisanaux (EPARECA), was founded in 1996. It was created because it was realized that poor people need attractive commercial spaces near their dwellings, which are also sociable spaces But its impact is still not obvious in terms of the location of small commercial units.

French and sometimes foreign architects have been asked to build new neighbourhood centres which would attract people from considerable distances. An effect close to that of the Gehry Guggenheim museum in Bilbao is sought, but is not achieved as the programme and building rules in France are more rigid than elsewhere. Lyon, Montpellier, Nîmes, Nancy, Nantes, Bordeaux... are the towns in which this new urban policy is most obvious but it is present everywhere.

But to attract people to the centre of the town raises the risk of traffic jams. This cultural policy is directly linked to a mobility policy, organizing the renewal of the tramway to take visitors to the centre from the external car park. All French cities with more than 200,000 inhabitants receive help from the state for this. The aim is to build more sustainable cities with better public transport, but it surely builds a new urban life, consumption in the centre and living on the outskirts where the land is cheaper, either in individual houses or in apartments.

On the outskirts buying food is not difficult, you can choose your commercial centre, but the public services, if not missing altogether, are organized in a cheap way and not up to 
the standard of those in the centre, which is not acceptable in the French republican framework. The problem can be seen especially with schools. The school used to be the very centre of the neighbourhood, the place in which all children were integrated into French society, and all schools under Jules Ferry's rule were supposed to be the same. But moving from one place to another in the metropolis, parents can see that schools are not really the same.

All the urban services are today under pressure of privatization and customization, which destroy their integrative capacity, and their ability to function in the part of the city where the poor are most numerous. As poorer people in France are often immigrants from North and Black Africa, the plight of the neighbourhood centre is all too evident. So it was decided in 1991 that all new building programmes should have 20 per cent apartments or houses for social housing; but as another law put student housing and middleclass housing in the social housing it did not change anything. A new law in 2000 made the communes responsible for building social housing. All urban communes should have 20 per cent houses or apartments devoted to social housing, for sheltering the poor.

Poor neighbourhoods house poor people for a long time, but shelter middle-class people for a short time, the time to save money to go elsewhere, into the supposed countryside. All public gardens have been places of social mix. In France the social demand seems at the moment, especially in the biggest towns, to open public gardens as local life centres. New types of gardens are being created in which, for instance, you can grow your own plants. The gardens are seen as places of diversity. It is probably necessary to think again about the space-time relations for those who go walking from their dwelling to 'something else'. The qualities of urban life, the events, the diversity, the nature in town are certainly the best antidote to urban sprawl. This antidote is linked to the necessity of rethinking the size of efficient neighbourhoods today.

\section{REFERENCES}

Ascher, F. (1995) Métapolis ou l'avenir des villes. Paris: O. Jacob.

Brossaud (2003) Le Vaudreuil ville nouvelle et son imaginaire bâtisseur. Paris: L'Harmattan.

Candilis, G., Josic, A. and Woods, S. (1975) Toulouse le Mirail, la naissance d'une ville nouvelle. Stuttgart: Karl Krämer Verlag.

De Saint Pierre (1998) La construction symbolique des espaces: Cergy Saint-Christophe en Ville Nouvelle. Paris: Maison des sciences de l'homme, SPPU.

Devisme, L. (2005) La ville décentrée. Figures centrales à l'épreuve des dynamiques urbaines. Paris: L'harmattan.

Fourcault, A. (2002) Régénérer la banlieue parisienne, les premiers grands ensembles, in Pranlas Descours, J.-P. (ed.), L'archipel métropolitain. Paris: Picard.

Lefebvre, H. (1967) Quartier et vie de quartier. Cahiers de l'IAURP, 7.

Lefebvre, H. (1968) Le droit à la ville. Paris: Anthropos.

Lefebvre, H. (1970) La révolution urbaine. Paris: Anthropos.

Mayol, P. (1994) "Le quartier, in De Certeau, M., Giard, L. and Mayol, P. (eds.) L'invention $d u$ quotidien, T2 Habiter, cuisiner. Paris: Seuil.

Mottez, M. (2003) Carnets de campagne. Evry 19652007. Paris: L'Harmattan.

Ostrowetsky (1994) Les centres urbains, in GhorraGobin, C. (ed.) Penser la ville de demain. Qu'est-ce qui institue la ville? Paris: L'harmattan. 